\section{幽闹 Digital Commons@}

Loyola Marymount University

LMU Loyola Law School
Loyola of Los Angeles International and Comparative Law Review

3-1-2009

\title{
The Price of European Identity: The Negative Social and Economic Impact of Slovenian Migration Law
}

Brett C. Rowan

Follow this and additional works at: https://digitalcommons.Imu.edu/ilr

Part of the Law Commons

\section{Recommended Citation}

Brett C. Rowan, The Price of European Identity: The Negative Social and Economic Impact of Slovenian Migration Law, 31 Loy. L.A. Int'l \& Comp. L. Rev. 221 (2009).

Available at: https://digitalcommons.Imu.edu/ilr/vol31/iss2/3

This Article is brought to you for free and open access by the Law Reviews at Digital Commons @ Loyola Marymount University and Loyola Law School. It has been accepted for inclusion in Loyola of Los Angeles International and Comparative Law Review by an authorized administrator of Digital Commons@Loyola Marymount University and Loyola Law School. For more information, please contact digitalcommons@lmu.edu. 


\title{
The Price of "European" Identity: The Negative Social and Economic Impact of Slovenian Migration Law
}

\author{
BRETT C. ROWAN*
}

Since its independence in 1991, Slovenia has become the most economically successful of the former Yugoslavian countries, as it is the only one to become a member of the European Union ("EU") and the only "Eastern" European country to implement the Euro. 'Those achievements, however, have come at a price. By choosing to join the EU, Slovenia has consequently been forced to adhere to EU migration policies, laws, and requirements of the Schengen Acquis ("Schengen"). ${ }^{2}$ This Article asserts that the adherence to such EU-dictated migration policies, laws, and Schengen has negatively impacted Slovenian culture and economic development. In addition, the structure, language, and administration of the Slovenian migration laws, in accordance with EU standards, are detrimental to its culture and economic

\footnotetext{
* Brett C. Rowan, J.D. (Washington University in St. Louis); B.A. (Providence College). I would like to thank Frances Foster for her helpful support, comments, and suggestions throughout the many drafts of the paper. I would also like to thank Fred Bloom for his guidance. This paper was originally presented on March 1, 2008, at Yale Law School at the 6th Annual Young Scholar's Conference on behalf of the Yale Journal of International Law. I would like to thank Robert B. Ahdieh for his helpful critique and suggestions from the conference as well as Harold Hongju Koh and the members of the Yale Journal of International Law.

1. See András Inotai \& Peter Stanovnik, EU Membership: Rationale, Costs, and Benefits, in SLOVENIA: FROM YUgOSLAVIA TO THE EUROPEAN UNION 353, 353-381 (Mojmir Mrak et al. eds., 2004); Slovenia Country Profile, THE ECONOMIST INTELLIGENCE UNIT, 2007, at 3 (Slovenia was the first eastern country to replace its currency with the Euro, which replaced the Slovenian Tolar on January 1, 2007, at a fixed exchange rate of 239.64:1). Although Cyprus and Greece are farther east than Slovenia, they are often not considered to be part of "Eastern" Europe because of their political histories.

2. See Treaty of Amsterdam Amending the Treaty on European Union, the Treaties Establishing the European Communities and Certain Related Acts, Oct. 2, 1997, 1997 O.J. (C 340), Protocol 2, at preamble, art. 1, Annex [hereinafter "Schengen Acquis"].
} 
development. The lessons from Slovenia's adoption of EU migration standards are important for both new EU members, specifically Romania and Bulgaria, and for other candidate countries to consider as possible consequences of EU accession.

Part I of this Article examines Slovenia's accession to the EU. Part II examines the EU's policies, laws, and Schengen requirements regarding migration. Part III analyzes the amendments and drafting of Slovenia's laws in adherence to EU standards. Part IV analyzes the negative cultural consequences to Slovenia from its migration policy and administration of that policy in accordance with EU's standards. Part V analyzes the negative economic consequences to Slovenia arising out of that same policy.

\section{SLOVENIA'S ACCESSION TO THE EU}

Following its independence from Yugoslavia, Slovenia sought to develop both culturally and economically and to shed its Socialist identity. ${ }^{3}$ In 1991, it established itself as a unitary parliamentary republic. ${ }^{4}$ Slovenia avoided much of the internal destruction seen in the neighboring states of Croatia, Bosnia and Herzegovina, and Serbia by creating a state with a homogenous ethnic identity. ${ }^{5}$ In order to develop the republic, it began the privatization of its former Socialist structure. ${ }^{6}$ In the same year of

3. Inotai \& Stanovnik, supra note 1, at 355-356, 362. See also Treaty of Accession to the European Union, Sept. 23, 2003, 2003 O.J. (L 236) [hereinafter AE Treaty].

4. Giacomo.Benedetto, Slovenia: Consensus, Integration and the Protection of Identity, in POLICY-MAKING PROCESSES AND THE EUROPEAN CONSTITUTION: A COMPARATIVE STUDY OF MEMBER STATES AND ACCESSION COUNTRIES 209 (Thomas König \& Simon Hug eds., 2006).

5. See generally Karmen Erjavec, Media Construction of Identity Through Moral Panics: Discourses of Immigration in Slovenia, 29 J. ETHNIC AND MIGRATION STUDIES 83 (2003).

6. INTERNATIONAL PRIVATIZATION 199, 201 (Dennis Campbell ed., Kluwer Law Int'1 1996) (Part of the former socialist Yugoslav republic, Slovenia created laws to gradually privatize.); THE LAW ON DENATIONALIZATION URADNI [SLOVN. C. CIV.] No. 27/91 (The Official Gazette of the Republic of Slovenia) (Slovn.), translated in http://www.lexadin.nl/wlg/legis/nofr/eur/lxweslv.htm; THE LAW ON CO-OPERATIVES [SLOVN. C. CIV] No.13/92, No. 7/93 (The Official Gazette of the Republic of Slovenia, 1999) (Slovn.), translated in http:/www.lexadin.nl/wlg/legis/nofr/eur/lxweslv.htm; LAW ON APARTMENTS [SLOVN. C. CIV] No.18/91 (The Official Gazette of the Republic of Slovenia, 1999) (Slovn.) translated in http://www.lexadin.nl/wlg/legis/nofr/eur/lxweslv.htm; LAW ON OWNERSHIP TRANSFormation OF SOCIALly OWNED COMPANIES URADNi [SLOVN. C. CIV.] No. 55/92, No. 7/93, No. 31/93, No. 43/93 (The Official Gazette of the Republic of Slovenia) (Slovn.), translated in http://www.lexadin.nl/wlg/legis/nofr/eur/lxweslv.htm; see Joze Mencinger, Privatization in Slovenia, 3 SLovN. L. REV. 65 (2006); Mojca Mihelj, Polona Tepina \& Urban Vrtačnik, The Slovenian Judiciary - A Guide Through Slovenian Courts, 3 SLOVN. L. REV. 209, 214 (2006). 
its independence, Slovenia drafted its constitution and legally established an ethnic Slovenian state distinct in homogeneity from its Yugoslav neighbors.' "The Republic of Slovenia was recognized as a sovereign state by the European Economic Community (EEC, the precursor to the EU) in January 1992." " Slovenia further established its sovereignty by joining the United Nations in February 1992. ${ }^{9}$

To continue its development, Slovenia looked to join the EU. The impetus for joining the EU was both cultural and economic. ${ }^{10}$ Slovenia sought to strengthen its economic capabilities by joining the growing EU to capitalize on the economic benefits of a common market. ${ }^{\text {"1 }}$ Many citizens, however, stated that their reasons for joining were not only economic but also due to the "Europeanization of values and thinking." ${ }^{12}$ Slovenia wanted to remove its associations with the war-torn neighboring Balkan states in favor of democracy and a "Western" societal structure as seen in the EU. ${ }^{13}$ The government and its citizens chose to join the EU to fully align their new democracy with Western Europe. ${ }^{14}$

7. CONST. OF THE REPUBLIC OF SLOVENIA art. 3. In creating its Slovenian state, however, the Slovenian Constitution guarantees special rights and protection to the indigenous Italian and Hungarian (European) minorities living within their border, but did not create protections for Yugoslav ethnic groups. Id. at art. 64. See Benedetto, supra note 4, at 209 (The republican structure was inspired by Germany and other parliamentary republic structures with a directly elected president with largely ceremonial powers and executive formation occurring as a result of legislative elections.).

8. Slovenia Country Profile, supra note 1, at 4.

9. Id.

10. Inotai \& Stanovnik, supra note 1 , at 355 .

11. Id. at 356 (Potential economic benefits of the EU include the elimination of trade barriers allowing small economies to participate in exportation and importation of goods as well as the establishment of a hard currency in the Euro.).

12. Nicole Lindstrom, Rethinking Sovereignty: The Politics of European Integration in Slovenia, 24 FLETCHER F. WORLD AFF. 31, 43 (2000) (Surveys of Slovenian citizens before joining the EU noted that the main reasons for Slovenians wanting to join the EU were (1) economic reasons, (2) the Europeanization of values and thinking, and (3) security against the Balkans and better relations with bordering EU countries.).

13. Id.. See also Inotai \& Stanovnik, supra note 1, at 356.

14. Public opinion was that the disassociation from its neighbors would be realized when Slovenia was known as an EU country rather than a former Yugoslavian socialist country. See Monitoring the EU ACCESSION PROCESS: Judicial INDEPENDENCE. 437-38 (Central European University Press) (2001) [hereinafter MONITORING THE EU ACCESSION PROCESS]. To be in line with the EU member states that Slovenia sought to join, "in mid-2004, several constitutional amendments were passed, explicitly guaranteeing equal opportunities for men and women to stand in the country's elections, equal rights for people with disabilities, and the right to a pension." Slovenia Country Profile, supra note 1, at 7. Under Article 22 of the Constitution of the Republic of Slovenia, the Slovenian Constitutional Court upheld the constitutional right to 
In December 2002, the EU Copenhagen Summit confirmed invitations for Slovenia and nine other countries to join the EU in May 2004. ${ }^{15}$ Slovenian citizens approved EU membership by a majority of approximately ninety percent in a referendum on March 23, 2003. ${ }^{16}$ Citizen approval allowed Slovenia to become a member of the EU in May 2004. ${ }^{17}$

\section{EU LAW REQUIREMENTS FOR MIGRATION}

EU authority is based on treaties and directives that are approved by the member states. ${ }^{18}$ The Treaty of Nice and the Treaty of Amsterdam are two recent treaties of the EU that amended both the former Treaty of the European Union and the Treaty of the European Community. ${ }^{19}$

The member states of the EU do not operate as a federal system like the United States, but are independent sovereign states. ${ }^{20}$ Nonetheless, the member states choose to "pool their sovereignty" and delegate some of their decision-making powers

the equal protection of rights by providing that: "Everyone shall be guaranteed equal protection of rights in any proceedings before a court and before other state authorities, local community authorities and bearers of public authority that decide on his rights, duties or legal interests, which is a reflection of the right to equality before the law." CONST. OF THE REPUBLIC OF SLOVENIA art. 22. Further, Article 14 of the Constitution of Republic of Slovenia provides that: "(1) In Slovenia everyone shall be guaranteed equal human rights and fundamental freedoms irrespective of national origin, race, sex, language, religion, political or other conviction, material standing, birth, education, social status or other political circumstance. (2) All are equal before the law." Id. at art. 14; Slovenia, System OF Justice IN TRANSITION: CENTRAL EUROPEAN EXPERIENCES SinCE 1989, 104, fn. 20-21 (Jiri Priban, Pauline Roberts \& James Young eds., Ashgate Publishing 2003) [hereinafter SYSTEM OF JUSTICE IN TRANSITION].

15. Slovenia Country Profile, supra note 1 , at 6.

16. Id. at 11 .

17. Id. There was a key tension between "integrationist," who were looking to take advantage of the open European markets and embrace a multicultural identity, against the "protectionist" ideas of absolute sovereignty and national identity. Lindstrom, supra note 12 , at 43.

18. Official European Union Website, http://europa.eu/abc/treaties.index_en.htm. There is currently a movement within the EU to adopt a common Constitution, which will replace the signed treaties and directives as lone authority; however, the Constitution has not been ratified by the member states and is not currently in effect. See The European Constitution 2004/C, 2004 O.J. (C 310) (EC).

19. Official European Union Website, supra note 18. The EU can be traced to The Treaty Establishing the European Coal and Steel Community in 1952. Similarly, the Treaty of Rome in 1958 formed the European Economic Community. The subsequent Single European Act of 1987 followed by the Treaty of the European Union at Maastricht in 1992 established the modern three-pillared structure of the European Union. Id. This Article focuses on the amendments made by the Treaty of Amsterdam because of the amendment's effects on migration law and policy.

20. Id. 
to the EU's institutions: the European Parliament, the Council of the European Union ("Council"), and the European Commission ("Commission"). ${ }^{21}$

The EU has not developed one comprehensive migration policy, but has developed a community acquis of various treaties, policies, and directives. ${ }^{22}$ The EU requires adherence to these laws and policies. ${ }^{23}$ The laws and policies of the EU regarding migration involve: 1) EU citizenship; 2) the free movement of persons in the EU; 3) the EU common visa policy; 4) the Schengen Acquis; 5) asylum directives; and 6) the integration policy. ${ }^{24}$

\section{A. EU Citizenship}

Article 17 of the amended Treaty of the European Community defines EU citizenship to include "[e]very person holding the nationality of a Member State." ${ }^{25}$ "Citizenship of the Union, which supplements national citizenship without replacing it; is made up of a set of rights and duties that add to those that are already attached to the citizenship of a Member State." ${ }^{26}$ The treaty permits member states to determine their own procedures

21. The primary responsibility of the European Parliament is to represent the EU citizens who elect them. The Council of the EU represents the individual member states, and the European Commission seeks to uphold the interests of the Union as a whole. The actions of the institutions are granted by the signed Treaties, which are ratified by the parliaments of the member states. See generally Treaty of Amsterdam Amending the Treaty on European Union, the Treaties Establishing the European Communities and Certain Related Acts arts. 3-5, Oct. 2, 1997, 1997 O.J. (C 340) (EC) [hereinafter Treaty of Amsterdam]; Treaty Establishing the European Economic Community art. 7, opened for signature Mar. 25, 1957, 298 U.N.T.S. 11, as amended Nov. 10, 1997, 1997 O.J. (C 340) [hereinafter EC Treaty]. The Council should be not confused with the Council of Europe which is a separate entity from the EU.

22. The Treaty of Amsterdam, supra note 21, art. 3, provides for cooperation between member states. The Treaty of Amsterdam has gradually replaced the EU Treaty's conventions with regulations requiring cooperation with respect to freedom, security, and justice regarding migration, organized crime, and trafficking. The Union sought to use the Treaty of Amsterdam to set up an area of freedom, security, and justice to address member states' concerns regarding immigration and asylum and to create closer cooperation between police forces and customs authorities. The term "acquis" is used in the EU to refer to the total body of EU law accumulated thus far.

23. Inotai \& Stanovik, supra note 1 , at 370.

24. See generally EC Treaty, supra note 21, art. 17; Schengen Acquis, supra note 2, art. 1; European Parliament and Council Directive on the Right of Citizens of the Union and Their Family Members to Move and Reside Freely Within the Territory of the Member States art. 1, 38/2004, 2004 O.J. (L 158) 77 (EC).

25. EC Treaty, supra note 21 , art. 17.

26. Id. 
for acquiring citizenship, but with limitations imposed regarding permanent residence and entry/exit regulations. ${ }^{27}$

\section{B. Free Movement of Persons in the $E U$}

The Treaty of the European Union as amended by the Treaty of Amsterdam stated that "the Union shall... maintain and develop... as an area of freedom, security and justice, in which the free movement of persons is assured in conjunction with appropriate measures with respect to external border controls, asylum, immigration and the prevention and combating of crime ...." 28

In order to address concerns that migration created crime and security risks, the Treaty of Amsterdam provided for a Common Foreign and Security Policy ("CFSP") in Title V. ${ }^{29}$ Article 11(1) stated the CFSP was to safeguard common values, strengthen security, and develop democracy, and mandated in 11(2) that "the Member States shall support the Union's external and security policy actively and unreservedly in a spirit of loyalty and mutual solidarity." ${ }^{30}$ The Treaty of the European Community as amended by the Treaty of Amsterdam defined the free movement of persons in Title III, Article 39, explaining that the "freedom of movement for workers shall be secured within the Community ... subject to limitations justified on grounds of public policy, public security or public health ...."

The European Parliament and Council Directive of April 29, 2004, merged all the legislation regarding the right of Union citizens and their families to move within the member states. ${ }^{32}$ The Directive explained that all Union citizens have the right to enter another member state for stays of less than three months and family members who do not have the nationality of a member state

27. Id. art. 6.1; Council Directive 38/2004, supra note 24; Schengen Acquis, supra note 2, art. 1.

28. Treaty of Amsterdam, supra note 21, art. 2.

29. Id. at Title V.

30. Id. art. 11.

31. EC Treaty, supra note 21 , art. 39. Member states have debated the language of the Article and directives have defined its interpretation. See Council Directive 38/2004, supra note 24 , art. 1.

32. Council Directive $38 / 2004$, supra note 24 , at preamble. The measure was adopted by the Union (and is in effect as of April 30, 2006) to provide a better understanding of the amended laws and treaties governing freedom of movement for Union citizens. See EC Treaty, supra note 21 , arts. 17-18. 
enjoy the same rights. ${ }^{33}$ Residency for longer durations is subject to certain conditions, including but not limited to demonstrating sufficient resources, employment, and/or registration with local authorities. ${ }^{34}$ The Directive, which replaced all previous directives, was drafted to help interpret and define misunderstandings and to assist in the proper administration of the freedom of movement as provided in the treaties. ${ }^{35}$

\section{EU Visa Policy}

Title IV of the EU Treaty directed the Council to adopt measures for visas and other policies related to the free movement of persons, as this was not specifically provided for in the treaties themselves. ${ }^{36}$ There are four Regulations of the European Parliament and of the Council establishing a common EU visa policy and Common Consular Instructions for the issuing of visas. ${ }^{37}$ The Regulations require member states to follow EU technical specifications, format, and procedure for issuing visas. They further require member states to designate not more than one local body to be responsible for printing visas, and member states must share information in the Visa Information System ("VIS") operated by Europol. ${ }^{38}$

EU law also requires a uniform format for residence permits. ${ }^{39}$ For immigration between states, EU law requires member states to grant permanent residence in its state for Union citizens and family members who are not Union citizens after a five-year period of uninterrupted legal residence. ${ }^{40}$

For third-country nationals, EU law requires adherence by member states to certain guidelines to protect security, justice, and the free movement of persons through the EU. Specifically, EU

33. Council Directive 38/2004, supra note 24, art. 6 .

34. Id. art. 7.

35. Id. at preamble.

36. EC Treaty, supra note 21 , at Title IV.

37. Commission Proposal for the Regulation of the European Parliament and of the Council Establishing a Community Code on Visas, at 3, COM (2006) 403 final (July 19); Council Regulation 333/2002, 2002 O.J. (L 53) 1 (EC); Council Regulation 1683/1995, 1995 O.J. (L 164) (EC); Council Regulation 539/2001, 2001 O.J. (L 81) 1 (EC).

38. Commission Proposal for the Regulation of the European Parliament and of the Council Establishing a Community Code on Visas, COM (2006) 403 final, art. 11. Specifications include biometric data, photo size, and identification requirements. The Schengen Acquis requires further uniformity. Treaty of Amsterdam, supra note 21, at Protocol B.

39. See Council Regulation 1030/2002, 2002 O.J. (L 157) 1 (EC).

40. Council Directive 38/2004, supra note 24, at preamble. 
law requires third-party nationals from a list of over one hundred countries to possess a visa to enter any EU member state. ${ }^{41}$ EU law also inhibits member states by limiting the admission of thirdcountry nationals for employment. ${ }^{42}$ Member states may only allow third-country nationals to fill employment vacancies that cannot be filled by "national and Community manpower or by nonCommunity manpower lawfully resident on a permanent basis in that Member State." ${ }^{43}$ Third-country nationals may be admitted temporarily when they are a specialist with professional qualifications. ${ }^{44}$ Seasonal workers may be admitted for six months maximum, trainees may be admitted for one year maximum, and other third-country employees may be admitted for four years maximum. ${ }^{45}$ Exceptions can be made to specific third-countries with close links to a member state. ${ }^{46}$ Students of third-party nations may be admitted if they have been accepted by an establishment of higher education in the member state and have sufficient resources. ${ }^{47}$

\section{Schengen Acquis}

One of the most substantial changes to the Treaty of the European Union made by the Treaty of Amsterdam was the incorporation of the Schengen Acquis into EU law. ${ }^{48}$ After the initial establishment of the free movement of persons caused debate, France, Germany, Belgium, Luxembourg, and the Netherlands created a territory without internal border checks known as the "Schengen Area" to facilitate movement between their nations. ${ }^{49}$ Schengen expanded to thirteen member states with the Treaty of Amsterdam incorporating the agreement into EU law in $1999 .^{50}$

41. Council Regulation 539/2001, supra note 37, art. 1 .

42. Council Resolution 20/1994, annex I.1, 1996 O.J. (C 274) 1 (EC).

43. Id.

44. Id.

45. Id.

46. Id.

47. Council Directive 114/2004, arts. 2 \& 7, 2004 O.J. (L 375) 12 (EC).

48. See Treaty of Amsterdam, supra note 21, at Protocol B (integrating the Schengen Acquis into the framework of the European Union).

49. The Schengen area was named for the town in Luxembourg where the agreement was signed in 1985. European Union, The Schengen Area and Cooperation, http://europa.eu/scadplus/leg/en/lvb/133020.htm (last visited May 10, 2009).

50. Treaty of Amsterdam, supra note 21, at Protocol B, arts. 1-2. Special provisions regarding Schengen requirements were reached with Denmark, Ireland, and the United Kingdom 
The main provisions of Schengen are: 1) the abolition of checks at internal common borders; 2) the adoption of common rules and procedures for entry/exit at external borders; 3) the separation in air terminals of those traveling within the Schengen states and those outside the area; 4) the adoption of common regulations of entry and visas for stays less than 90 days; 5) the coordination of surveillance of borders; 6 ) the coordination of measures to combat illegal immigration; 7) a requirement that non-EU nationals moving from one state to another must register with the state; 8 ) a requirement to follow the Dublin Convention regarding examination of asylum seekers; 9) the cooperation of judicial systems for extradition proceedings; and 10) the creation of the Schengen Information System ("SIS") to coordinate technology for border patrol and police checks. ${ }^{51}$ Slovenia and the member states that joined the EU after the Treaty of Amsterdam are bound by the entire Schengen Acquis, but implementation of all of the requirements of Schengen is not required at the time the state joins the EU. ${ }^{52}$

\section{E. Asylum Directives}

Article 63 of Title IV of the EU Treaty directed the Council to adopt measures for asylum. ${ }^{53}$ In accordance with the Geneva Convention of 1951 and the New York Protocol of 1967, the EU

who did not want to be required to follow all of the Schengen requirements. EC Treaty, supra note 21, art. 69. Other European countries who are not EU members (Iceland, Norway, Switzerland, and Liechtenstein) have chosen to sign Schengen. Council Decision 2000/365, 2000 O.J. (L 131) 43 (EC); Council Decision 1999/435, 1999 O.J. (L 176) 1 (EC).

51. European Union, The Schengen Area and Cooperation, supra note 49. Cooperation between member states is required for establishing border control, combating illegal immigration, drug trafficking, money laundering, and organized crime, police and legal cooperation, data protection and mutual recognition of court judgments.

52. Treaty of Amsterdam, supra note 21, at Protocol B, arts. 1-2. The EU requires adoption of the Schengen criteria in the law when admitting a member state, but it does not require the actual implementation at the time the state joins the EU. The EU wants to adhere to the goal of security, justice, and the free movement of persons, and therefore, uses timetables for implementing the Schengen Agreement with new member states. The binding rules which new member states must have in place as soon as they join include some of the rules on visas, the rules governing external borders and migration, asylum, police cooperation, the fight against organized crime, terrorism, fraud, corruption, drug trafficking, customs cooperation and legal instruments relating to human rights. With regards to issues such as border control, illegal immigration, drug trafficking, money laundering, organized crime, police and legal cooperation, data protection and mutual recognition of court judgments, the new member states must be administratively capable of dealing with them with an organized judiciary and reliable, effective police department.

53. EC Treaty, supra note 21 , art. 63. 
adopted asylum procedures which are required for all member states. ${ }^{54}$ Member states must allow applicants the freedom of movement within their territory. Additionally, they must maintain certain reception conditions with respect to food and clothing, family unity, and medical and psychological care. ${ }^{55}$. Further, member states must provide access to the education system for minor children and access to language courses for all applicants. ${ }^{56}$ Member states must delegate a national contact point, cooperate with other member states, and ensure that appropriate measures are in place to promote "harmonious relationships between local communities and accommodation centres. ..."

In 2003, the Council replaced the Dublin Convention of 1990 with the Dublin II Regulation, which delegates asylum applications throughout the EU. ${ }^{58}$ The new regulation requires member states to assess, on the basis of objective and hierarchical criteria, which member state is responsible for examining an asylum application lodged with their territory in order to prevent asylum shopping, as each asylum application is to be examined by only one member state. ${ }^{59}$

Member states are required to appoint authorities to examine asylum applications with specialized personnel reviewing all applications "individually, objectively, and impartially." If the application is rejected, the state must make it possible to appeal to a court or an independent reviewing authority.

\section{F. Integration Policy}

One of the goals of the Treaty of the EU was to take further steps in "enhancing European integration." ${ }^{62}$ The Council developed directives introducing "vigorous integration policies for

54. See Council Resolution 20/1995, 1996 O.J. (C 274) 13 (EC), (on minimum guarantees for asylum procedures); Council Directive 2003/9, 2003 O.J. (L 31) 18 (EC) (laying down minimum standards for the reception of asylum seekers).

55. See Council Directive 2003/9, supra note 54, arts. 7-8, 13-15.

56. Id. art. 10

57. Id. at preamble.

58. Council Regulation 343/2003, 2003 O.J. (L 50) (EC).

59. Id. The regulation establishes "the criteria and mechanisms for determining the Member State responsible for examining an application for asylum lodged in one of the Member States by a third-country national." Id. art. 1.

60. Council Resolution, 20/1995, supra note 54, at preamble.

61. Id. art. 19.

62. Treaty of Amsterdam, supra note 21, at Protocol 2, preamble. 
third country nationals in the EU." ${ }^{63}$ The Council found that most member states agree that integration involves "a two-way process involving both immigrants and their community" based on reciprocal rights and concomitant obligations of legally resident third-country nationals and the host society. ${ }^{64}$ According to the $\mathrm{EU}$, integration means that "the longer a third-country national resides legally in a member state, the more rights and obligations [he or she] should acquire." ${ }^{\circ 5}$ The integration policy regarded language as the largest obstacle to "successful integration," explaining that those without language skills cannot produce economic output. ${ }^{66}$

The Council encouraged governments to create holistic integration approaches to ensure that immigration would benefit both demographic and economic challenges. ${ }^{67}$ The Commission stated that "basic knowledge of the host society's language, history, and institutions is indispensable to integration," and argued that the integration component be strengthened through pre-departure measures and introduction programs offering courses at several levels and that innovative integration models be supported in order for immigrants to integrate into European culture and values. ${ }^{68}$ The Commission warned that intercultural and interfaith dialogue must be encouraged to ensure European integration and participation in civil society, rather than subjecting immigrants and refugees to discrimination. ${ }^{69}$

\section{Slovenian Migration Law is Aligned with EU LaW}

The Slovenian government created its migration legislation to mirror EU policies, laws, and the Schengen requirements. The Treaty of the European Union as amended by the Treaty of Amsterdam provides:

63. Communication from the Commission to the Council, the European Parliament, the European Economic and Social Committee and the Committee of the Regions on Immigration, Integration, and Employment, at 35, COM (2003) 366 final (Mar. 6).

64. Id. at 44 .

65. Id. at 18 .

66. Id. at $19-20$.

67. Id. at 18 .

68. Communication from the Commission to the Council, the European Parliament, the European Economic and Social Committee and the Committee of the Regions: A Common Agenda for Integration, Framework for the Integration of Third-Country Nationals in the European Union, at 7, COM (2005) 389 final (Sept. 9).

69. Id. at 19. 
A European State may apply to become a member of the Union ... [but] the conditions of admission and the adjustments to the Treaties on which the Union is founded, which such admission entails, shall be the subject of an agreement between the member states and the applicant State. This agreement shall be submitted for ratification by all the contracting States in accordance with their respective constitutional requirements. $^{70}$

Slovenia followed the Treaty of Accession to the EU in order to align its laws to qualify for EU membership."

The Commission monitored Slovenia's progress and in 1997, stated that Slovenia had aligned its immigration and asylum law in adherence to EU policy, but it had failed to establish sufficient border control. ${ }^{72}$ In 1999, after amending its migration laws, Slovenia completed the alignment of its legislation, but needed to still complete alignment, particularly in the areas of border controls and drugs. ${ }^{73}$ In its November 2000 Report, the Commission noted, "the harmonization of legislation and the strengthening of the administration had been priorities for the Slovenian Government. Nevertheless, further efforts were needed to improve external border controls." "T4 The Commission criticized Slovenia for its inability to combat organized crime, trafficking, and drugs, but administratively, procedurally, and legislatively, Slovenia was almost entirely aligned with Schengen. ${ }^{75}$

With its independence and creation of administrative and judicial structures, Slovenia's legislature drafted the Aliens Act,

70. Treaty of Amsterdam, supra note 21, art. 49.

71. AE Treaty, supra note 3, arts. 33-49.

72. In 1997 and 1998, before the laws were fully amended, the Commission stated that Slovenia's migration laws were too restrictive and encouraged the government to make progress on immigration, right to asylum, and border controls, but noted that "Slovenia should be in line with the EU rules on justice and home affairs within the next few years." Commission Opinion, COM (1997) 2010 final (July); Commission Report on the Accession Partnership from the EU Directed Slovenia in What was Required in Order to be Accepted into the EU, COM (1998) 709 final (Nov.); Republic of Slovenia, Intergovernmental Conference on the Accession of the Republic of Slovenia to the European Union, Negotiating Position of the Republic of Slovenia on Chapter 2 Freedom of Movement of Persons, http://www.svez.gov.si/fileadmin/svez.gov.si/pageuploads/docs/negotiating_positions/2.doc.

73. Commission Report on Slovenia's Application for Membership of the European Union and the State of Negotiations, COM (1999) 512 final (Sept. 19, 2000).

74. Commission Report on Slovenia's Application for Membership of the European Union and the State of Negotiations, COM (2000) 712 final (July 18, 2001).

75. Commission Comprehensive Monitoring Report of the European Commission on the State of Preparedness for EU Membership of the Czech Republic, Estonia, Cyprus, Lativia, Lithuania, Hungary, Malta, Poland, Slovenia and Slovakia, COM (2003) 675 final (Nov. 5). 
the Citizens Act, and the Asylum Act in 1999, which remain the laws regulating migration (these were supplemented with the State Border Control Act of 2003). ${ }^{76}$ Slovenia drafted its laws in anticipation of joining the EU and transposed EU law into the Aliens Act using nine of the EU directives." The migration laws of Slovenia follow the policies and laws of the EU regarding: 1) citizenship; 2) the free movement of persons in the EU; 3 ) the visa policy; 4) the Schengen Acquis; 5) the asylum directives; and 6) the integration policy. ${ }^{78}$

\section{A. Citizenship}

Chapter XII.A of the Aliens Act sets out the requirements for the entry and residence of citizens of the EU member states and their family members into Slovenia. ${ }^{79}$ As member states' citizenship procedures are not dictated by EU law, Slovenia has created its own regulations to acquire its citizenship. However, rights are conferred to EU citizens with respect to entry/exit and permit requirements. These rights are listed in Articles 93a-93ac of Slovenia's Aliens Act in conformity with the Treaty of the EU. ${ }^{80}$

76. Aliens ACT [SLOVN. C. Crv.] No. 87/2002, No. 17/10-2002, RS 93/2005, 21/10-2005 (The Official Gazette of the Republic of Slovenia, 1999) (Slovn.), translated in http://www.lexadin.nl/wlg/legis/nofr/eur/lxweslv.htm; CITIZENS ACT [SLOVN. C. CIV] No. 61/99 (The Official Gazette of the Republic of Slovenia, 1999) (Slovn.), translated in http://www.lexadin.nl/wlg/legis/noff/eur/lxweslv.htm; STATUS OF CITIZENS OF OTHER SFRY SUCCESSOR STATES LIST [SLOVN. C. CIV.] No. 61/99 (The Official Gazette of the Republic of Slovenia, 1999) (Slovn.), translated in http://www.lexadin.nl/wlg/legis/nofr/eur/lxweslv.htm; Status OF CitIZENS OF OTHER SFRY SUCCESSOR STATES List [SLOVN. C. CIV.] No. $61 / 99$ (The Official Gazette of the Republic of Slovenia, 1999) (Slovn.), translated in http://www.lexadin.nl/wlg/legis/noff/eur/lxweslv.htm; STATE BORDER CONTROL ACT [SLOVN. C. CIV.] No. 126/2003, No. 18/10-2003, No. 69/2005 (The Official Gazette of the Republic of Slovenia, 1999) (Slovn.), translated in http://www.lexadin.nl/wlg/legis/nofr/eur/lxweslv.htm; Asylum ACt [SLOVN. C. CIV.] No. 61/1999, No. 66/2000, No. $113 / 2000$, No. $124 / 2000$, No. 67/2001, No. 98/200 (The Official Gazette of the Republic of Slovenia, 1999) (Slovn.), translated in http://www.lexadin.nl/wlg/legis/nofr/eur/lxweslv.htm.

77. ALIENS ACT, supra note 76, art. 1 (2) ("This Act transposes the following directives of the European Union into the legislation of the Republic of Slovenia: Council Directive 2001/40/EC of May 28, 2001 on the mutual recognition of decisions on expulsion of third country nationals . . . Council Directive 2001/51/EC . . supplementing the provisions of Article 26 of the Convention implementing the Schengen Agreement . . Council Directive 2002/90/EC . . . defining the facilitation of unauthorised entry, transit, and residence . . Council Directive 2003/110/EC . . . on assistance in cases of transit for the purposes of removal by air.").

78. Id.

79. Id. art 93a-ac.

80. Id. 


\section{B. Free Movement of Persons}

Following EU law, Article 93b of the Aliens Act states that "EU citizens shall not require any entry permit ... for entry into the Republic of Slovenia." ${ }^{81}$ Article 93c, in line with EU law, requires EU citizens to file a registration of residence if the citizen will remain in Slovenia for more than three months. ${ }^{82}$ The EU directive explained that all Union citizens have the right to enter another member state for stays of less than three months. ${ }^{83}$. Family members who do not have the nationality of a member state enjoy the same rights. ${ }^{84}$ Slovenia follows that directive, but requires registration for stays longer than three months, in accordance with EU standards. ${ }^{85}$ The Act states that "[a] long-term resident and his or her immediate family members who have a residence permit in another EU Member State can enter the Republic of Slovenia with a valid passport and the residence permit issued in another EU Member State." ${ }^{86}$

The Treaty of the European Community, as amended by the Treaty of Amsterdam, defined the free movement of persons in Title III, Article 39. It states that "freedom of movement for workers shall be secured within the Community... subject to limitations justified on grounds of public policy, public security or public health ... " ${ }^{87}$ "Provisions for Refusal" in the Aliens Act also follow EU regulations regarding public health, public policy, and security. ${ }^{88}$

\section{Visa Policy}

Slovenia's visa and residence permit policy is fully aligned with the EU. ${ }^{89}$ Slovenia established Slovenian passports and the

81. Id. art. $93 \mathrm{~b}$.

82. Id. art. $93 \mathrm{c}$.

83. Council Directive 38/2004 supra note 24, art. 6.

84. Id.

85. ALIENS ACT, supra note 76, art. 93c

86. Id. art. 8.

87. EC Treaty, supra note 21, art. 39; Member states have debated the language of the Article and directives have defined its interpretation. Council Directive 38/2004, supra note 27.

88. ALIENS ACT, supra note 76, art. 9. Refusal of entry into Slovenia for "suspicion that he may pose a threat to public order and safety or the international relations of the Republic of Slovenia." Id.

89. Id. art. 5(2) Migration Policy stating that Slovenia will cooperate with other countries and international organizations in the area of migration and that "the Government of the Republic of Slovenia shall determine annually the number (quota) of residence permits which may be issued to aliens in the current year." See also id. at arts. 7, 14-21, 26-30. 
issuing of visas at border posts in 2001. Furthermore, Slovenia established the EU mandated procedures and technical specifications for issuing visas. ${ }^{90}$ New member states have to adopt the EU's strict visa policy, requiring nationals of a long list of countries to apply for a visa in order to gain entry to the EU, regardless of visa-free regimes with their eastern and southern neighbors. ${ }^{91}$

EU law requires member states to grant permanent residence for Union citizens in its member state after a five-year period of uninterrupted legal residence..$^{22}$ The same rule applies for family members who are not Union citizens. Slovenia mirrors this law exactly in Article 41 of the Aliens Act, which states, "[a] permit for permanent residence may be issued to an alien who has resided in the Republic of Slovenia uninterruptedly for five years on the basis of a permit for temporary residence." ${ }^{93}$ Residence permits adhere to the EU policies indicating the requirements in Article 46 of the Aliens Act. ${ }^{\prime \prime}$

Third-country employees may obtain work permits based on the Aliens Act and the Slovenian Employment Act. These acts established minimum EU employment standards of third-country nationals. ${ }^{95}$ In Article 32 of the Aliens Act, Slovenia followed the EU's dictated requirements for issuing employment-based visas for non-EU citizens. ${ }^{96}$ Consistent with EU regulations, Article 32 indicates that quota systems will be used and observed when issuing employment permits. ${ }^{97}$

The European Parliament Directive, which concerns the posting of workers in the framework of the provision of services,

90. Id. art. 14 ("A visa shall be a permit issued by the competent body of the Republic of Slovenia to an alien" mandating that transit and entry visas may be issued); Id. art. 21 (setting out the form and content of visas in agreement with the Minister of Foreign Affairs).

91. Catherine Phuong, Enlarging "Fortress Europe": EU Accession, Asylum, and Immigration Laws in EU Candidate Countries, 52 INT'L \& COMP. L.Q. 641, 647 (2003). ALIENS ACT, supra note 76 , art. 8 (permit required by aliens unless otherwise determined by law to enter Slovenia).

92. Council Directive $38 / 2004$, supra note 24 , at preamble.

93. ALIENS ACT, supra note 76, art. 41.

94. Id. art. 46.

95. Tomaz Petrovic \& Jasna Habic, Labor and EMPloyment LaW IN THE NEW EU MEMBER AND CANDIDATE STATES 331 (Anders Etgen Reitz ed., 2007).

96. ALIENS ACT, supra note 76, art. 32. Permits for temporary residence for residence in another EU member state are dictated in Article 30, which states that temporary residence permits shall be "issued to aliens who have the status of a long-term residence in another EU Member State." Id.

97. Id. 
has also been implemented. ${ }^{98}$ In accordance with EU law, permits for seasonal work are issued for no more than six months and employment permits are issued for no more than one year; however, they may be extended to a maximum of two years.

Following EU regulations, Article 33 states that "aliens accepted ... in suitable educational institutions in the Republic of Slovenia shall have the right to reside in the Republic of Slovenia for the duration of their study." ${ }^{100}$ Students of third-party nations may be admitted if they have been accepted by an establishment of higher education in the member state and have sufficient resources. ${ }^{101}$

\section{Schengen Acquis}

Although concessions were made for previous EU member states - Denmark, Ireland, and the United Kingdom - the EU requires new member states to follow the requirements of Schengen to ensure justice, security, and free movement of persons within the EU. ${ }^{102}$ Certain provisions will apply to new members only after both proper common border controls have been abolished and external border controls have been established. ${ }^{103}$ Slovenia drafted the necessary legislation with respect to: 1) the regulations of entry and visas for stays less than 90 days; ${ }^{104} 2$ ) the coordination of measures to combat illegal immigration; ${ }^{105} 3$ ) the requirement that non-EU nationals moving from one state to another must register with the state; ${ }^{106} 4$ ) the requirement to follow the Dublin Convention regarding examination of asylum

98. Council Directive 96/71, 1996 O.J. (L 18) 1 (EC).

99. ALIENS ACT, supra note 76, arts. 32, 34. Slovenia's laws are stricter than the four years permitted by the EU.

100. Permits are issued at one-year intervals. Id.

101. See Council Directive 114/2004 (EC).

102. Treaty of Amsterdam, supra note 21, at preamble.

103. A list of the elements, which make up the Schengen Acquis, setting out the corresponding legal basis for each of them in the Treaties, was adopted on May 20, 1999. Council Resolution 20/1994, supra note 42, art. 4. They will be abolished by the Council when the SIS is operational in their countries and when those member states have undergone a test to show that they meet all the conditions required for the application of compensatory measures enabling internal border controls to be abolished.

104. ALIENS ACT, supra note 76, arts. 6-24.

105. Id. arts. 47-62 ("Departure from the Country and Annulment of Residence Regarding Illegal Immigration.").

106. $I d$. 
seekers; ${ }^{107}$ 5) the cooperation of judicial systems for extradition proceedings; ${ }^{108}$ and 6 ) the creation of SIS to coordinate technology for border patrol and police checks. ${ }^{109}$

[C]andidate countries have to comply with the obligations arising from Schengen before benefiting from the advantages in terms of abolition of internal border controls and free movement of persons. In other words, tougher border controls must first be applied on the eastern borders of the candidate countries, and only then will concession be made on their western borders. ${ }^{110}$

The EU assists new member states with the implementation of the required controls because the resources needed for their implementation are extensive. Technology is especially difficult to implement as Schengen requires a database exchange between EU member states to provide uniformity in their procedures. ${ }^{111}$ Internal border checks have been lifted and, as of 2008, Schengen is fully implemented in Slovenia. ${ }^{112}$ Special procedures were created to allow Croatian citizens to enter Slovenia without obtaining a visa. ${ }^{113}$ Negotiations are underway to alleviate

107. ASYLUM ACT, supra note 76, art. 24(5).

108. ALIENS ACT, supra note 76, art. 66.

109. Id.

110. Phuong, supra note 91, at 648 (emphasis added).

111. European Union, The Schengen Area and Cooperation, supra note 49. In order to reconcile freedom and security, the SIS was set up as a sophisticated database used by the authorities of the Schengen member countries to exchange data on certain categories of people and goods. In addition, SIS was created so that the national authorities responsible for border controls and other customs and police checks carried out in their countries and for the coordination of these controls, together with the judicial authorities of these countries, can obtain information on persons or objects. Member states supply information to the system through national networks (N-SIS) connected to a central system (C-SIS), and this IT system is supplemented by a network known as SIRENE (Supplementary Information Request at the National Entry). This network is the human interface of the SIS. See Council Resolution 20/1994, supra note 42; see also Hans-Jorg Albrecht, Fortress Europe? - Controlling Illegal Immigration, 10 EUR. J. CRIME CRIM. L. \& CRIM. JUST. 1, 13 (2002) ("Slovenia predicts that instead of 700 police now on duty at the southern (and future Schengen-) border 3000 will be needed to comply with Schengen border control standards.").

112. Frattini: Schengen Entry Christmas Gift for Slovenia, SLOVENIAN PRESS AGENCY, Sept. 11, 2007, available at http://www.mnz.gov.si/en/splosno/cns/news/period/1232998719// /article/11982/5554/?cHash $=9$ ad9b00cfl.

113. See Republic of Slovenia, Schengen: Frequently Asked Questions, http:/www.mnz.gov.si/en/pogosta_vprasanja/faq_about_schengen/ (last visited Aug. 3, 2009) ("Croatian citizens are allowed to enter Italy, Hungary and Slovenia with an identity card accompanied by a card containing personal data: first name, last name and identity card number. The card is stamped on each entry into and exit from those countries. Identity cards (accompanied by a special card) are allowed only for Italy, Hungary and 
restrictions to other countries in the Western Balkans; however, it is unclear if these policies will actually benefit those communities or simply create more procedural hurdles. ${ }^{114}$

Slovenia has furthered discussions surrounding the proposed European Constitution as well as a common immigration policy. ${ }^{115}$ The EU has pressured Slovenia to better maintain its southern and eastern borders, stating that the borders are commonly circumvented by illegal immigrants. ${ }^{116}$ This pressure led to the

Slovenia. Croatian citizens are required to carry a passport in order to enter other countries; they are required to present it at external border control (i.e. on entering Slovenia) so that an entry stamp is placed in it. Otherwise, their entry into other states is considered illegal.").

114. See Press Release, European Union, Commission Launches Dialogue with the Former Yugoslav Republic of Macedonia on Visa Free Travel (Feb. 20, 2008), http://europa.eu/rapid/pressReleasesAction.do? reference=IP/08/273\&format=HTML\&age $\mathrm{d}=0$ \&language $=$ en\&guiLanguage $=\mathrm{en}$; Press Release, European Union, Commission Launches Dialogue with Montenegro on Visa Free Travel (Feb. 21, 2008), http://europa.eu/rapid/pressReleasesAction.do?reference=IP/08/277\&format=HTML\&age $\mathrm{d}=0$ \&language $=$ en\&guiLanguage $=\mathrm{en}$; Press Release, European Union, Vice President Frattini in Tirana to Launch Visa Free Travel Dialogue with Albania (Mar. 6, 2008), http://europa.eu/rapid/pressReleasesAction.do?reference=IP/08/398\&format=HTML\&age $\mathrm{d}=0$ \&language $=$ en $\&$ guiLanguage $=e n$.

115. "The most significant institutional actor with the Slovenian executive was the EU Section in the Ministry of Foreign Affairs, responsible directly to Dimitrij Rupel, the Foreign Minister. This office has coordinated the Slovenian position through the [Intergovernmental Conferences]. . . . The inter-institutional task force also received input directly from the prime minister's office, and the Government Office of European Affairs. Its competence was limited to coordinating the accession negotiations and was staffed by personnel delegated from other ministries. It therefore specialized in all matters concerned with the EU other than institutional affairs." Benedetto, supra note 4, at 211-12. "Apart from the identity-related areas of vital interests, there was a wide-spread support for integrationist positions, particularly on burden sharing in the Area of Freedom, Security and Justice. Slovenia has a population of 2 million but a $1,000 \mathrm{~km}$ border. with Croatia, for which Slovenian officials are open about their need of assistance in policing ... the Slovenian government was rethinking its position on social policy, consistent with its neo-liberal economic policies. The changing approach to tax and social policy revealed some close proximity to the British position and may be linked to the influence of chambers of commerce." (emphasis included). Id. at 213. During the IGC, "Slovenia retained a short list of non-negotiable vital interests. These are connected to questions of identity for a small country and concern the composition of the European Commission, a minimum of five MEPs per state, and the conservation of Slovenian as its official language. The government, like the majority of governments, also opposed any move toward QMV (Qualified Majority Voting) over tax, CFSP (Common Foreign Security Policy) and ESDP (European Security and Defense Policy). The only vital interest protected by neither the draft constitution nor the eventual new treaty was the composition of the Commission." (emphasis included). Id. at 215-16.

116. Republic of Slovenia Government Communication Office, Slovenia is Preparing to Establish a Schengen Border, http://www.ukom.gov.si/eng/slovenia/backgroundinformation/schengen-border/ (last visited Feb. 24, 2009). 
Border Patrol Act, which came into force in January 2003. ${ }^{117}$ Since 2008, Slovenia sought to gain influence in Schengen policy after it hosted the Presidency of the EU Council. It was the first of the former Communist EU member states to host the position, which it did for the first six months of $2008 .{ }^{118}$

\section{E. Asylum Directives}

The Asylum Act, as required by EU law, follows the Geneva Convention and New York Protocols in establishing a procedure for granting asylum to aliens. ${ }^{119}$ Slovenia adopted procedures for the reception and accommodation of foreigners in residential centers in October 2000. ${ }^{120}$ In July 2002, Slovenia adopted amendments to the Temporary Protection Act with the aim of improving the status of the displaced persons from Bosnia \& Herzegovina who had temporary protection status for up to ten years.

117. STATE BORDER CONTROL ACT, supra note 76 , art 1 . The Act constituted new legislation determining the authorities responsible for border checks and surveillance.

118. "The main priority in 2007 will be preparations for the EU presidency...the key issues facing Slovenia's presidency include the strengthening of the European area of freedom, security and justice and the debates on the future of the EU, the European Constitution, enlargement and the Schengen zone." Slovenska Tiskovna Agencija: Government Adopts Draft Declaration on Slovenia's EU Priorities, BBC MONITORING EUROPE - POLITICAL, Jan. 25, 2007 [hereinafter Slovenia's EU Priorities]. "Prime Minister Janez. Jansa believes the EU could tackle immigration more efficiently if it adopted a common policy on the issue. Migration, just like energy, will constantly crop up at the sessions of the EU Council, the Slovenian prime minister said after the close of the EU summit in Brussels on Friday [15 December] . . . [the summit] pledged to improve cooperation among member states in fighting illegal migrations and secure better protection of the bloc's borders." Slovenska Tiskovna Agencija: Slovenian Premier Favors Common EU Immigration Policy, BBC Monitoring EuROPE - POLITICAL, Dec. 15, 2006; Slovenian Presidency of the EU Council, http://www.eu2008.si/en/index.html (last visited Aug. 3, 2009). The focus of the presidency was devoted to the implementation of the Lisbon Treaty, which was rejected by Ireland and has not been ratified. See JENSPETER Bonde, From EU CONSTITUTION TO Lisbon TREATy (2008), http://www.j.dk/exp/images/bondes/From_EU_Constitution_to_Lisbon_Treaty_april_2008 .pdf; Lisbon Treaty Referendum to Be Held on October 2nd, THE IRISH TIMES, July 8, 2009 , available

http://www.irishtimes.com/newspaper/breaking/2009/0708/breaking28.htm.

119. "The Republic of Slovenia shall grant asylum to aliens who request protection on the grounds stipulated in the Geneva Convention Relating to the Status of Refugees and the Protocol relating to the Status of Refugee[s]." ASYLUM ACT, supra note 76, art. 1(2).

120. Id. In 2003 the asylum-seekers' centre in Ljubljana was separated from the foreigners centre (centre for illegal immigrants). Justice, Freedom and Security, Enlargement - Slovenia Adoption of the Community Acquis, http://europa.eu/scadplus/leg/en/lvb/e22110.htm (last visited Apr. 18, 2009).

121. Id. 
The police demanded a change of the Asylum Law and requested that the Slovene government put pressure on the governments of Croatia, Hungary and Bosnia Herzegovina so that these countries too start guarding their borders according to European standards. The authority of the [EU] was used explicitly to legitimate these demands.

The EU, and then Slovenia in the Asylum Acts, adopted minimum procedures required for the member states. ${ }^{123}$ Slovenia, in accordance with EU law, allowed applicants freedom of movement within their territory, reception conditions with respect to food and clothing, family unity, medical and psychological care, and access, for minor children, to the education system and language courses.

As required by the EU, Slovenia delegated a national contact point, established coordination with other member states, and created measures to promote "harmonious relationships between local communities and accommodation centres...." Article 24 of the Asylum Act provides for a procedure to assess, on the basis of objective and hierarchical criteria, whether asylum should be granted. ${ }^{126}$ The procedure for hearing a claim is established in Articles 29 through 40 of the Act. ${ }^{127}$ This is done pursuant to EU regulations that review of claims must be done "individually, objectively, and impartially" with the ability to appeal. ${ }^{128}$

122. Erjavec, supra note 5, at 85-86. "The police 'forgot' to mention that the statistics showed no substantial increase in crime committed by immigrants and that Slovenia had received funds from the EU for the costs of dealing with immigrants . . . at the end of December 2000, the government quickly changed the Asylum Law, claiming that the change would improve national security." Id. at 86.

123. Council Resolution, 20/1995, supra note 54; Council Regulation 343/2003, supra note 58; ASYLUM ACT, supra note 76.

124. ASYLUM ACT, supra note 76, arts. 9-19. Article 9, "Assistance to Applicants" indicates their rights to lodge their applications, a legal counselor, and a UNHCR representative. Article 12 provides for interpretation and Article 19 provides for "integration assistance" by means of language courses, training, and establishing "conditions for the integration of refugees into the cultural, economic and social life of the Republic of Slovenia... and informing refugees about the Slovene history, culture and constitution." See Council Resolution, 20/1995, supra note 54; Council Regulation 343/2003, supra note 58.

125. Council Directive 2003/9, supra note 54.

126. ASYLUM ACT, supra note 76, art. 24. Council Regulation $343 / 2003$, supra note 58 , art. 4 establishes the criteria and mechanisms for determining the member state responsible for examining an asylum application lodged in one of the member states by a third-country national.

127. ASYLUM ACT, supra note 76 , at 29-40.

128. Council Resolution, 20/1995, supra note 54, at preamble. 


\section{F. Integration Policy}

Chapter $\mathrm{X}$ of the Aliens Act at Article 82 requires the government to assist with the integration of aliens.

The Republic of Slovenia shall ensure conditions of the inclusion of aliens... in particular, organise courses in the Slovene language ... provide information necessary for the inclusion of aliens in Slovenian society, particularly with regard to their rights and obligations, and opportunities for personal and social development; acquaint aliens with Slovene history, culture, and constitutional order; [and] organize joint events with Slovene nationals for the purpose of promoting mutual recognition and understanding. 129

The immigration policy adopted by the National Assembly in 1999 stated that

[I]ntegration is one of the three constituent parts of Slovenia's migration policy.... [I]ntegration is linked to so-called 'Slovenian values'; it is interpreted as a right to preserve migrants' own culture, which has to be practiced, however; according to the 'basic values of... Slovenia.' The aim of integration is also defined as enabling migrants to 'become responsible participants in the social development of Slovenia. ${ }^{130}$

129. ASYLUM ACT, supra note 76 , at art. 82. "Slovene integration policies widely refer to migration management models of other EU countries, and are not inspired by, for example, Canadian or Australian experiences, not to mention the absence of reference to broader global perspectives. Slovenia has learnt the policies of migration management by observing the process of adopting provision in different 'old' EU member-states, for example Germany, the UK, France or Sweden, and it is to these countries' experiences that the Slovene administration is constantly referring while adopting migration and integration bills. Although migration and integration institutions in these countries vary, they all share the mind-set of the need to preserve the foundation and values of a nation-state." Mojca Pajnik, Integration Policies in Migration Between Nationalising States and Transnational Citizenship, with Reference to the Slovenian Case, $33 \mathrm{~J}$. ETHNIC \& MIGRATION STUD. 849, 850-51 (2007).

130. Id. at 851-52; Ministry of the Interior, Integration of Refugees, available at www.mnz.gov.si [hereinafter Integration of Refugees] (requiring that immigrants and refugees learn the Slovenian language, take courses on Slovenian culture, history, and the Constitution of the Republic of Slovenia, and actively seek employment); REGULATION ON THE RIGHTS AND OBLIGATIONS OF REFUGEES IN THE REPUBLIC OF SLOVENIA, Nos. 33/2004, 129/2004 (Official Gazette of the Republic of Slovenia) (on file with author); THE ASYLUM ACT - ZAZIL-UPB1, No. 134/03 (Official Gazette of the Republic of Slovenia) (on file with author); EU Council Presidency Programme in the Area of Justice and Home Affairs, For a Freer and Safer Europe, available http://www.mnz.gov.si/fileadmin/mnz.gov.si/pageuploads/SOJ/2008/za_svobodnejso.pdf. 
The Ministry of the Interior 2005 Internal Administrative Affairs Directorate in its Refugees and Aliens Integrations Section defines integration as "a process of inclusion of refugees into the environment of the Slovenian society, considering the cultural, social, linguistic and other characteristics of this society, and considering the general way of life in it... integration is an individual process that starts by acquiring the right for asylum in the Republic of Slovenia, based on a personal integration plan." ${ }^{131}$

In adopting EU policy, Slovenia struggled to implement all of the EU's legislation and properly administer its laws. Procedures at border check points were especially difficult to implement due to the necessary "fundamental change of attitude ... from border guards who now have to 'keep foreigners out rather than keep citizens in." "132 Though Slovenia followed EU mandates to establish the Community acquis, its administration of the laws suffered. ${ }^{133}$

While independence has helped establish a civil society free from political influence on the judiciary branch of government, administration of the laws has not been efficient. ${ }^{134}$ This inefficiency has led some to doubt the country's legitimacy. The urgent need of parties involved in economic and family troubles to have their cases processed has forced the legislature to create difficult implementation standards. ${ }^{135}$ This has led to a decrease of foreigners into Slovenia legally and an increase in antagonism regarding immigration. ${ }^{136}$ Slovenia followed the policies, laws, and

131. Pajnik supra note 129 , at $852-53$.

132. Phuong, supra note 91 , at 647 .

133. " $[\mathrm{N}]$ on-binding . . . instruments were supplemented by . . the Dublin Convention on asylum and the Schengen Implementation Agreement, which contains some provisions dealing with asylum . . . so far, very few instruments have been adopted and are now clearly part of the EU asylum Acquis to be adopted by candidate countries." Id. at 651; "Although the European Convention of Human Rights in principle applies to all residents, the naturalisation procedures keep migrants with limited civil, domicile, and employment rights that are strictly regulated across the Schengen and Dublin borders." Pajnik, supra note 129, at 857.

134. "[B]y solving the problem of political influence on the courts, the Slovenian courts, like other courts within the civil law tradition, have not yet resolved the other problem, which is the increase in court delays resulting from a wider range of disputes in society." SYSTEM OF JUSTICE IN TRANSITION, supra note 14, at 107 (arguing for de jure binding effect of judge decisions rather than de facto effect in order to make the decisions valid sources of law).

135. See United States Department of State, Country Report on Human Rights Practices in Slovenia (2006), http://www.state.gov/g/drl/rls/hrrpt/2006/78839.htm, which states that the government passed a law amending asylum procedures and providing for an expedited review process by border police which could prevent the applications from receiving a thorough review.

136. Erjavec, supra note 5, at 98. 
requirements of EU migration law and established procedures for administration and policing of the laws. Nevertheless, Slovenia has been negatively impacted.

\section{SLOVENIAN MigRation LaW ALIGNED With EU LAW HARMED THE SLOVENIAN CULTURE}

Slovenian migration law has harmed Slovenian culture by cutting off Slovenian cultural identity from its historical roots, blaming domestic problems on migration, painting immigrants as "folk devils," ${ }^{137}$ and isolating cultural development, especially from influences on customs. Slovenia has invented its own national identity "not in the sense of a selective process of memory, but in terms of selecting 'new' values (being civilized, being European)." ${ }^{138}$ These tactics endanger the civil liberties of immigrants and refugees who enter Slovenia and are coerced into adopting "genuine Slovenianness." ${ }^{139}$ While mechanisms are in place to preserve freedoms in the European court system, civil society and cultural attitudes undermine individual freedoms to speak native languages, practice religion, and other forms of expression that are seen as not conforming to European values. ${ }^{140}$

While adapting to the uniform standards of EU membership, Slovenia maintained a dedication to preserving its language, culture, and traditions through its integration policy. ${ }^{141}$ Citizens have criticized Slovenia's migration policies and border enforcement as burdens on Slovenian culture. ${ }^{142}$ The government, hoping not to lose Slovenian identity in the process of gaining a European identity, has created policies calling for the foreign-born to integrate completely into the culture of Slovenian society rather

137. "Illegal immigrants and asylum-seekers were presented as folk devils. They were the scapegoat for all the real and imagined national problems." Id. at 87.

138. Id. at 98 .

139. Pajnik, supra note 129 , at 853 .

140. Id. at 850-54 (discussing integration, and specifically the personal integration plan). With its independence, Slovenia constructed a new identity and created an us versus them dynamic. Erjavec, supra note 5, at 98 . "National leaders gained an advantage by evoking a world structured around an absolute antagonism. ... [W]ith the media promoting fear and distrust, the new leaders validated their call for mobilising the nation to wage war against internal and external enemies, thereby securing its hold on repressive state apparatuses." Id. at 83 .

141. Pajnik, supra note 129, at $851-52$ ("integration is linked to so-called 'Slovene values;' it is interpreted as a right to preserve migrants' own culture, which has to be practiced . . . according to the "basic values of the "Republic of Slovenia." ).

142. See generally id. 
than incorporate the positive aspects of foreign-born people as a benefit for Slovenia.

Slovenia follows the EU model of migration policy, which suggests that in order for a member state to maintain cultural sovereignty it must fully support itself culturally as a nationstate. ${ }^{144}$ Legal requirements, such as an official language, create barriers that have a negative impact on Slovenian society. Even though Slovenian is the official language of Slovenia, other languages are unofficially recognized as spoken languages, such as Serbo-Croatian. ${ }^{145}$ Although the public relations and media office for Slovenia states that Serbo-Croatian does not exist in Slovenia since its independence, two European languages (Magyar and Italian) are accepted languages in certain border locations. ${ }^{146}$ This demonstrates the commitment of Slovenia to enhancing its Western image, and reinforces the argument that it views its historic ties to the Balkans as unimportant to its cultural identity, but rather views its ties to its new EU partners as not a threat to its cultural sovereignty.

Regardless of its preference for Western countries over its Balkan neighbors, Slovenia does not encourage foreigners to move, invest, or study in its country. ${ }^{147}$ While EU countries such as the United Kingdom, France, and Germany have incentives for foreigners to develop there because of the world-wide popularity of their native languages, large economies, and large urban cities, Slovenia automatically has barriers because of its local language, small economy, and small cities. ${ }^{148}$ Larger eastern EU countries like the Czech Republic and Hungary boast large cosmopolitan

143. "[M]igrant people should be viewed as having the potential for injecting something new into society. Migrants have the potential to look with 'new eyes' and to break the existing exclusionary patterns. They may represent the departure point for the disruption that is necessary for positive and progressive change. Instead of clinging to tradition, being without a burden of tradition allows us to see the world from new perspectives without being bound by prescriptions of how to handle potential innovations that emerge." Id. at 853,862 .

144. "The nation-state is thus legitimized by the very use of integration as an institutional mechanism that, by prescribing and changing the right to asylum, managing border control, ... etc. solidifies its goal, i.e. the preservation of the national." Id. at 856 .

145. COUNTRY WATCH, 2007 COUNTRY REVIEW: SLOVENIA, 103, available at http://www.countrywatch.com/cw_default.aspx.

146. In Slovenia, it was reported that about 155,000 people speak the Serbo-Croatian language. Since 1991, however, people in the Balkan area have become increasingly sensitive about these issues related to national identity. Id.

147. See, e.g., ALIENS ACT, supra note 76 (setting out policies for aliens to reside, work, and study in Slovenia).

148. COUNTRY WATCH, 2007 COUNTRY REVIEW: SLOVENIA, supra note 145. 
capitals in Prague and Budapest that have attracted many multinational people and corporations since their independence, but Slovenia's capital, Ljubljana, has not enticed foreigners in the same respect. Instead of facilitating foreign development in its country to overcome the barriers of its language and size, Slovenia has kept foreigners out by maintaining the stringent visa and permit policies of the EU, following its integration policies, and administering the law strictly. ${ }^{149}$ The strict adherence to its integration policy for immigrants and its cultural barriers which deflect EU citizens from relocating there, limit the introduction of other philosophy, art, culture, and thought to Slovenia, and ultimately negatively impact its society.

In contrast, other new EU member states embrace foreign students, for example. By developing internationally-focused universities with a widely-spoken language, such as English, in the belief that the social and economic benefits will outweigh the sacrifice of not mandating the national language or strictly preserving national sovereignty, countries such as the Netherlands, Belgium, and even Estonia have benefitted. The influxes of international students in Utrecht and Leuven have produced great academic achievements, cultural understanding, and economic benefits. The institutions develop more educated national workforces as well as create international business connections and tourism, and export the Dutch and Belgian cultures by sending native students to study abroad. Slovenia has refused to allow major educational institutions to speak in any language other than Slovenian. ${ }^{150}$ "Slovenia's sleepy and inward-looking public institutions are certainly ripe for change. In the global highereducation market, for example, Estonia boasts dozens of institutions offering competitively priced, multilingual courses. Some attract students of medicine and veterinary science from next-door Finland; increasingly, Asians come, too. By contrast, independent higher education in Slovenia is held back by grueling bureaucratic obstacles." ${ }^{151}$ Rather than focusing on spreading its cultural heritage, celebrating its customs, and serving as an example to other former Socialist countries on its effective democratic transition, Slovenia focused on maintaining cultural

149. SySTEM OF JUSTICE IN TRANSITION, supra note 14 , at 107.

150. When Small is Beautifully Successful, THE ECONOMIST, Oct. 15, 2005, at 53.

151. Id. 
sovereignty. While the citizens specifically sought to join the EU in order to align itself with the West, it has been culturally isolated in fear of immigration and ineffective border security.

Slovenia maintains the EU policy's ideology that efficient border control will provide internal security, political stability, and positive regional neighbor relations. ${ }^{152}$ Yet, Slovenia has not been able to successfully establish its border with Croatia and media representations have tied regional immigration to crime, further breaking down regional relations and failing to address internal problems by focusing externally.

Policing of immigration has caused internal problems in Slovenia due to police and media bias against foreigners. While Slovenians maintain unfavorable attitudes toward police intervention into personal liberty and privacy, Slovenian police reportedly harass refugees and other immigrants more without consequence. ${ }^{154}$

In early September 2000, the Slovene media began to regularly publish news items about the numbers of people caught crossing the southern and eastern borders (with Croatia and

152. By becoming a member of the EU, Slovenia is bound by the regulations of Schengen and must implement those EU policies. "The EU is still under the illusion that efficient border control mechanisms can ensure internal security. For a start there is no such thing as perfect border controls and migrants who are persistent will always find a way in. In any case, border controls alone cannot stem the flow of migrants or ensure the EU's internal security: the EU must also address the causes of migration...through its foreign and aid policies. It is also in the interest of the EU to ensure political stability in the region and maintain good relations with its immediate neighbors. It is thus important that it respects candidate countries' special relationships with their eastern neighbors, instead of imposing its own policies on them without taking into account their foreign policy interests." Phuong, supra note 91, at 663.

153. Erjavec, supra note 5, at 85,87 . "Immigration in Europe since the early sixties has been associated with crime and other social problems and therefore immigration has also become a central topic in the debates on safety in EU countries." Albrecht, supra note 111, at 5; Slovenia's EU Priorities, supra note 118. "Since the break-up of the former Yugoslavia, relations between Slovenia and Croatia have, at times, been strained by disagreements concerning their border demarcation. Recent talks between Slovenia and Croatia seek to resolve some of these difficulties." Slovenia Country Profile, supra note 1, at 61.

154. See Albin Iglicar, Understanding Human Rights and Protection Thereof in the Slovenian Legal Perception, 1 SLOVN. L. REV. 55, 61 (2004). Brank Lobnikar et al., Slovenian State Officials, Slovenian Citizens, and Refugees in Slovenia: How They Perceive Each Other, 10 EUR. J. CRIME CRIM. L. \& CRIM. JUST. 193, 196 (2002). "About 75 percent of the police officers studied were of the opinion that illegal immigrants committed criminal offences more frequently than Slovenians. Media portraits of illegal immigrants frequently support their opinion. But in fact, the statistical crime data show that refugees, foreigners and illegal immigrants commit a negligible number of criminal offences. It is interesting that police officers were aware of their negative attitudes toward illegal immigrants and blamed it on the bad working conditions." Id. Erjavec, supra note 5 , at 85 . 
Hungary) illegally. In October and November, the Directorate of the Slovene police, police stations in the border areas and the police trade union organised press conferences and sent out news releases in which they reported the numbers of illegal immigrants, all of whom were portrayed as criminals, violent people, carriers of dangerous infectious diseases, who threaten national security and on whom taxpayers' money is spent. In their reports they used metaphors of threats, including frequent use of terms such as 'flood,' 'waves' of immigrants etc. 155

The amended Asylum Law limited the freedom of movement of illegal immigrants and asylum-seekers. ${ }^{156}$ Media accounts further legitimized the law, establishing antagonism between Slovenians and foreigners. ${ }^{157}$ By the first week of February 2001, however, news reports on illegal immigrants virtually disappeared because the law had reinforced the national identity and appeased the public. ${ }^{158}$

By joining the EU, Slovenia's citizens hoped to improve regional relations and further the goal of "Europeanization." ${ }^{159}$ These goals have created a ninety percent ethnic Slovenian population ${ }^{160}$ that has distanced its culture from the other former Yugoslavian countries. ${ }^{161}$ Slovenia's migration policy has negatively affected its society by creating an "us" versus "them" mentality. ${ }^{162}$ Slovenia created this mentality by severing itself from connections to Socialism and the former Yugoslavian countries, and by seeking to associate itself with democracy, stability, and European ideals. ${ }^{163}$ Rather than improve regional relations, this dichotomy adversely affected its Slovenian national identity by creating hostile ethnic divides and limiting trade and development in the Balkans.

Following its independence, in 1991, ${ }^{164}$

Slovenia faced the first wave of approximately 50,000 refugees from Croatia. The second wave of Bosnian refugees followed in

\footnotetext{
155. Erjavec, supra note 5, at 85 .

156. Id. at 86 .

157. Id.

158. See id.

159. Id. at 98 .

160. Slovenia Country Profile, supra note 1, at 14.

161. Erjavec, supra note 5, at 98.

162. See id. at $86-87,99$.

163. Id. at 98.

164. Slovenia Country Profile, supra note 1, at 4.
} 
the beginning of 1992 . In total there were approximately 170,000 refugees in Slovenia between 1992 and 1996. In 1994, the majority of Croatian refugees returned to Croatia, and after the Dayton agreement some 19,000 refugees from Bosnia and Herzegovina returned to their country of origin as well. A small number of refugees from Kosovo came to Slovenia in $1998 .{ }^{165}$

These immigrants and refugees were portrayed as scapegoats for the internal problems of Slovenia. ${ }^{166}$ The media and political discourse created a Slovenian identity, instilling the unity of the ethnic Slovenian's heritage and creating fear and distrust for the foreign-born, particularly refugees ${ }^{167}$ In a complete break with the Balkans, Slovenian culture was isolated from its historical ties to the former Yugoslavian countries, and its new, independent culture was aligned with that of Europe. ${ }^{16}$

In response to the refugees in Slovenia, the media created a moral panic. ${ }^{169}$ The media dedicated a great deal of attention to the Bosnian refugees entering Slovenia in 1992 as a "threat to national security," ${ }^{170}$ but the issue ceased to exist when a law was created to close the Slovenian border to Bosnian refugees and restrict the rights of refugees already in Slovenia. ${ }^{171}$ The media's construction created and confirmed the consensus on solving the "refugee problem," and established an ethnic antagonism between "us" (Slovenian citizens) and "them" (foreign born). ${ }^{172}$ It has been argued that the specific ethnic antagonism toward neighboring groups enabled Slovenia to escape civil war by building a strong sense of community. ${ }^{173}$ Nonetheless, although Slovenia repaired

165. Lobnikar et al., supra note 154, at 192 (footnote omitted).

166. Erjavec, supra note 5, at 87 . In instilling the 'us' and 'them' values through political discourse, and legitimizing them through the legal construction of their 'integration' policies of their immigration and refugee law, Slovenia has invented their own national identity not in the sense of a selective process of memory, but in terms of selecting 'new' values (being civilised, being European) ..." Id. at 98 .

167. Id.

168. The media allowed Slovenia to establish an identity by consensus, creating a community that shared the same configuration of knowledge, beliefs, and values. The media referred to nationality as a shared story about the Slovenian identity, the representation of "us" against "them." Id.

169. See id. at 96.

170. Id.

171. Id. at 86,96 .

172. Id. at 96 .

173. See id. 
regional relations with EU members Italy and Austria, it has failed to do so with any of the former Yugoslavian countries. ${ }^{174}$

Integration is incompatible with Slovenian attitudes and needs, and it undermines, rather than promotes, Slovenian development. Slovenian citizens were willing to join the EU in part because they desired to develop regional relations and benefit from European ideals. ${ }^{175}$ Influence from other cultures and regional relations, however, directly conflicted with practices of forced cultural integration. Slovenia has not been able to flourish culturally or economically because of the barriers created by the migration policy.

Based on this linear understanding, integration is envisioned as a process that keeps the Slovene society intact. By its very definition, integration promotes the phantasmic image of Slovenia as a homogenous entity... [i]nstead of promoting an active manifestation of difference, integration is practiced as migration policy, as a rule according to which migrants have to become adapted to what is constructed as genuine Slovenianness .... ${ }^{176}$

Slovenia romanticizes foreign-born culinary, dance, and music traditions, but strips any political ideologies, philosophy, or insight that will disrupt Slovenia or its law. ${ }^{177}$ "[M]igrants are expected to fulfill the expectations determined by the [Slovenian-born]... [and by creating immigration and refugee law that promotes] integration as an individual rather than a collective responsibility[,] [Slovenia] produces a situation where people compete rather than exchange experience[s]." "178

Media portrayals of immigrants as the source for internal problems and political discourse, arguing EU membership as a solution for security problems, demonstrates further misalignment with Slovenian citizens. ${ }^{179}$ Slovenians have lost trust in their government because they have seen a breakdown rather than an increase in security through EU membership. ${ }^{180}$ The Slovenian

174. See Slovenia Country Profile, supra note 1, at 12.

175. Erjavec, supra note 5, at 98 .

176. Pajnik, supra note 129 , at 853 .

177. Id. at 860 .

178. Id.

179. Erjavec, supra note 5, at 96.

180. Iglicar, supra note 154, at 70; Slovenska Tiskovna Agencija: Slovenian Customs Officials Find $40 \mathrm{~kg}$ of Cocaine on Belgium-bound Ship, BBC MONITORING EUROPE POLITICAL, Aug. 24, 2007 [hereinafter Customs Officials Find $40 \mathrm{~kg}$ of Cocaine]. 
government shifted the burden to the EU to protect its citizens. ${ }^{181}$ Simultaneously, they have shifted the blame for security to Croatia and the Balkans, which have used Slovenia as a trafficking hub. ${ }^{182}$

Media portrayals and policing treatment of immigration has created an antagonistic "us" (European, civilized, Slovenian) against "them" (foreign-born, problematic, non-European) structure in Slovenia. The law's policy of integration, along with poor administration of immigration law and asylum claims, maintains this antagonistic structure. ${ }^{183}$ The government has cut off Slovenian cultural identity from its historical roots, creating hostility towards its neighbors in the Balkan States. Former Yugoslavian citizens who once formally shared territory are now seen as an unwelcome "them." 184

Isolating cultural development mandates homogeneity. Even when integration policies are viewed as positive structures assisting the foreign-born in Slovenia, it demonstrates that the "us" versus "them" structure is antagonistic. Anyone raised outside of Slovenia will never fully integrate into such a sharp ethnic divide. Procedures to assist immigrants with language and history will not allow anyone to really be "Slovenian." Even if legally deemed to be "Slovenian," the immigrant is still faced with threats of infringement on his or her individual rights and media portrayals of the immigrant as a "folk devil." ${ }^{185}$ Slovenia joined the EU, partially, in hopes to become more aligned with Western Europe, but it has affirmatively and passively sought to maintain its cultural isolation. Through its implementation of the laws and policies as required by its accession to the EU, the migration policy has impacted Slovenia more significantly than other member states. Indeed, all of the EU's policies do not apply universally to all of its members, and Slovenia serves as an example of the consequences of joining the EU and seeking to benefit from a multi-state structure without analyzing the negative impact it may have on its society.

181. See Iglicar, supra note 154 , at 70 .

182. See Customs Officials Find $40 \mathrm{~kg}$ of Cocaine, supra note 180.

183. See SYSTEM OF JUSTICE IN TRADITION, supra note 14, at 107; Erjavec, supra note 5, at 85-87; Pajnik, supra note 129 , at 852-54.

184. Erjavec, supra note 5, at 96.

185. Id. at 87 . 


\section{SLOVEnian MigRation Law Aligned with EU Law HARMED THE SLOVENIAN ECONOMY}

As demonstrated through its implementation of the Euro, ${ }^{186}$ Slovenia's economy has benefited in succumbing to the EU requirements. ${ }^{187}$ Nonetheless, Slovenia has failed to benefit from its full economic potential due to the same integrationist values that have negatively impacted its society. Slovenia has been adverse to foreign investment and tourism, while failing to develop outside businesses and trade. ${ }^{188}$ Just as Slovenia has not welcomed foreign influence on its customs, language, and education systems, the country has deterred international business development.

Slovenia developed economic benefits from the West while still part of the former Yugoslavia, ${ }^{190}$ but has maintained distance from foreign investors and enterprises. ${ }^{191}$ Slovenia has been reluctant to allow foreign ownership amid scattered job loss and stagnant management structures.

In addition, Slovenia has not fully benefited economically from its strategic position through tourism. One citizen noted that, "[e]ven well-educated Europeans think we are Slovakia. Which, I'm sure you realise, is another country entirely.' With a

186. CIA Factbook, supra note 1, at 519; Slovenia Country Profile, supra note 1, at 3.

187. CIA Factbook, supra note 1, at 519; Inotai, supra note 1, at 354-56.

188. Slovenia Country Profile, supra note 1 , at 21.

189. Although Slovenia has the highest GDP per capita of the eight new member states in Central and Eastern Europe, Slovenia is still unknown to many Europeans and many others internationally because of its hesitance to expand tourism and its restrictions on refugees, immigrants and foreign investment. See Benedetto, supra note 4, at 209.

190. "The Slovenian republic was the trading arm of the former Yugoslavia, and thus local firms built strong links built with Western partners. Slovenia's links with the West, however, provided wider benefits than just profits from trade. Many Slovenian factories obtained Western technology through licensing agreements in the 1970s and 1980s, which enabled them to become internationally competitive. Real GDP has grown steadily since a post-independence dip. In 2006 real GDP grew by a seven-year high of $5.2 \%$, driven primarily by a construction-related surge in business investment." Slovenia Country Profile, supra note 1, at 20.

191. "To the mild irritation of the international financial institutions and foreign investors looking to break into the local market, the government adopted a gradualist approach to economic reform, maintaining that the country's relatively advanced level of development rendered irrelevant the "shock therapy" type of reform programmes that the other east-central European countries adopted in the early 1990s. Slovenia is also the only east European country never to have had an IMF programme, allowing successive governments more leeway in policymaking." Id. at 21 .

192. "The FDU/GDP ratio in 2003 was 20.7 percent, and Slovenia has remained the only former socialist country with the majority of the banking sector in domestic ownership." Mencinger, supra note 6, at 73; Stefan Bojnec, Privatization, Restructuring and Management in Slovenian Enterprises, 41 COMP. ECON. STUD. 90, 91 (1999). 
population of two million, sandwiched between Austria, Italy, Hungary and Croatia, self-satisfied and quietly prosperous little Slovenia has never quite put itself on the map." "Ljubljana is ready. It has great hotels, picture-postcard canals and bridges, a gorgeous sprawling park, restaurants and bars galore. Mentally, it is still in denial.'

"Ethnic Slovenes make up almost $90 \%$ of the population ... The population is ageing and authorities estimate that the working-age population group will decline as a percentage of the total over the next ten years." 195 With an almost homogenous population, Slovenia has developed a state that clearly is neither attractive to multinational companies seeking to establish a new business location nor foreign-born people seeking to move. Yet, the nice climate, high living standard, and strategic location would provide many benefits for foreigners and foreign business. The government's migration policy creates barriers to foreigners and international business, especially from non-EU countries. Such laws discourage international businesses from moving employees to or opening facilities in Slovenia. ${ }^{196}$ Slovenia's asylum law is also antagonistic to foreigners and has granted astoundingly few asylum applications. ${ }^{197}$

Many of Slovenia's largest industries have sharply declined. ${ }^{198}$ The service and construction industries, however, have grown.

193. Viv Groskop, Don't Let on About the Truffles, NEw STATESMAN, Apr. 26, 2004, at 19.

194. Id. at 19.

195. Slovenia Country Profile, supra, note 1, at 14-15 ("At the time of the 2002 census, those aged 15-59 made up 64\% of the population and the forecast for 2012 for the same age group is $61 \%$. The population as a whole is expected to grow even more slowly in the coming decade, with Eurostat (the EU's statistical office) forecasting growth of $0.6 \%$ in 2007-17.").

196. See COUNTRY WATCH, supra, note 145, at 115, ("Slovenes place a premium on personal contact and correspondence and visits play significant roles in the conduct of business in Slovenia. Clarity and continuity in communication are important.").

197. See Pajnik, supra note 129 , at 854 ("[T] here exists a large gap between the procedurally grounded rights and the practical exercise of these rights, but also because there is something obviously wrong with the asylum policy of a country that, in a span of ten years, had granted asylum to a total of 124 people-whereas the number of asylum applications has exceeded 16,000.") (footnote omitted).

198. Slovenia Country Profile, supra note 1, at 20 "'Traditional industries such as textiles and truck-making, have contracted sharply since independence, but there has been an increase in light manufacturing and higher value-added sectors such as pharmaceuticals and electrical engineering ... weaker industries, particularly textiles and food and beverages, have suffered significant output declines-forcing some to merge to preserve or boost their competitiveness."). 
Nonetheless, Slovenia has failed to benefit from the positive aspects of foreign workers who contribute to those industries. ${ }^{199}$

The labor market remains relatively inflexible and over protected, and pay scales in public service are complicated and do not reward performance.... In June 2007, the government had to raise the quota for non-EU workers in Slovenia to 24,500 for the year, up from 18,500, as booming conditions in sectors such as construction raised demand for workers. ${ }^{200}$

Slovenia's policy of issuing only a limited amount of work permits to non-EU workers and failing to properly administer its migration laws impacts its economy. ${ }^{201}$ Slovenia's adoption of the

199. See South East Europe Monitor, 11 EMERGING EUROPE MONITOR 1 (Business Monitor International, London, UK 2004) at 2-6. (EU accession and an ageing population will make changes to the official budgetary system imperative). See also Slovenia Country Profile, supra note 1, at 20-21 ("Services as a percentage of gross value-added (GVA) have grown from around $50 \%$ at the time of independence to $57 \%$ in 2006 for three main reasons. First, the country along with most of western Europe, has experienced strong growth in provision of information-based services, and a broader economy-wide shift away from traditional "smokestack" service industries. Second, with improving integration both among western Balkan countries and between the western Balkans and the EU, Slovenia has taken advantage of its geographical position to improve transport links in the country and benefit from higher services receipts in this sector. Third, investment in infrastructure and quality enhancements in the tourism industry have led to healthy growth in tourism service receipts."). Accord Bojnec, supra note 192, at 100 (companies in the "catering and tourism" industries raised from 484 to 2,313 between 1990 and 1996.); SLOVENIA, MAIN Findings of THE AUTUMN REPORT, InSTITUTE FOR MACROECONOMIC $\begin{array}{llll}\text { ANALYSIS AND DEVELOPMENT } & 62-63 & \text { (2006), }\end{array}$ http://www.umar.gov.si/fileadmin/user_upload/publikacije/aanaliza/ajesen06/ajporocilo2006.pdf (Employment rose especially in construction and business services, as well as in hotels and restaurants, transport, financial information, metal and machinery industries and some public services.).

200. Slovenia Country Profile, supra note 1, at 23.

201. See Martin Baldwin-Edwards, Semi-Reluctant Hosts: Southern Europe's Ambivalent Response to Immigration, 8 Brown J. World Aff. 211, 225 (2001-2002) ("[T]he biggest policy failure across southern Europe has been the inability of the state to adapt to changing global patterns, to accept migration as a reality of the late twentieth century, and to manage it in economic, social and political terms. By persisting with exclusionary patterns of immigration control-notably issuing very few work permits, setting absurd conditions for employers to recruit illegal labor, horrendous bureaucracy in the applications process--southern European governments closed off legal labor recruitment. At the same time, they made no effort to control their borders. Thus the phenomenon of an expanding informal sector began, staffed principally by illegal immigrants who accepted the terms of their host country. The informal employment of immigrants has done much for economic growth, and in particular has propped up entire ailing industries - but at a cost. That cost has been borne by the illegal immigrants themselves, who are socially excluded, and by the indigenous population, which feels somehow threatened all this illegality. It has also set back the normal process of social integration of immigrants, although this is now proceeding at a reasonable pace in Spain and Italy, despite governments which are broadly anti-immigrant."). Accord SYSTEMS OF JUSTICE IN TRADITION, supra note 14, at 107; Pajnik, supra note 129, at 853 ; see also Erjavec, supra note 5, at 87. 
Euro, small population, and highly export-oriented manufacturing sector make Slovenia completely dependent on EU market conditions. ${ }^{202}$ Further, growth is limited to designated industries as Slovenia has failed to develop the information technology sector, which may be linked to a stagnant and isolated workforce and education system. ${ }^{203}$

\section{CONCLUSION}

In a country where its citizens appreciated its accession to European values, Slovenia's adoption of its migration policy and procedures is problematic. ${ }^{204}$ Slovenia followed EU law as mandated by the Treaty of Amsterdam; as well as the Treaty of the European Union and the Treaty of the European Community, and the directives of the Council, Commission, and the European Parliament to enter the EU.

In a conscious effort to disassociate itself from Socialist principles, Slovenia drafted its migration laws to cut off its society from the East and align itself with the West. The creation of these migration laws followed the EU policy of integration which created an "us" versus "them" antagonistic structure. Further, Slovenia's particular administration of the migration laws, especially asylum law, reinforced the antagonism to maintain ethnic homogeneity.

202. Slovenia Country Profile, supra note 1, at 13, 24-33; see also South East Europe Monitor, supra note 199, at 6 ("Slovenia no longer has an independent monetary policy which could be used to slow the economy, and neither does it have an independent exchange rate policy. This therefore means that the government has to be vigilant in ensuring that the suitability of fiscal policy, both to ensure overheating does not occur and to maintain labor competitiveness.")

203. See Slovenia Country Profile, supra note 1, at 33 ("A persistent deficit in business services is a result of the fact that the restructuring process had left Slovenian companies increasingly reliant on such foreign services as royalty agreements, insurance and consultancy. Sophisticated business services, patents and licenses are being imported from the US as part of the development of information technology (IT) in Slovenia. ... [t] $]$ he share of business services, insurance, and IT services is low, and well below that of most other EU members."). See Polona Pičman Stefančič, Slovenian Civil Society in the Information Age: Are We There Yet?, 2 SLovN. L. REV. 137, 139 (2005); see also THE STRATEGY OF THE REPUBLIC OF SLOVENIA IN THE INFORMATION SOCIETY

http://unpan1.un.org/intradoc/groups/public/documents/UNTC/UNPAN015723.pdf.

(2005),

204. See Pajnik, supra note 129, at 854 ("[J]udgment[s] about whether reasons to grant asylum are well-grounded can be provided by the police . . . free legal aid in the beginning of the asylum procedures has been abolished. . . the new law has transferred the jurisdiction to appoint refugee counselors from the Ministry of Justice to the Ministry of the Interior. . . social security provisions have been lowered as well as the rights to work and be mobile within the country.") (footnote omitted); accord SYSTEM OF JUSTICE IN TRANSITION, supra note 14, at 107; see also Erjavec, supra note 5, at 87. 
Media portrayals have blamed internal problems on immigration, and Slovenia continues to call for a comprehensive EU migration law to protect its new European values from the East. Slovenian citizens have not truly benefited from the migration policy culturally or economically. Migration laws throughout Europe have created threats to civil liberties for migrants, and new political movements. This phenomenon, seen especially in France and Austria, demonstrates that the antagonism created by migration law is not isolated to Slovenia. Yet, Slovenia's size, history, location, and economy demonstrate the impact the law and the administration of the law has on culture and economics. These lessons from Slovenia provide insight for the governments and citizens of those countries seeking accession to the EU and those who have recently joined as to what negative effects may coincide with the benefits of EU membership. 
